Review

\title{
The Regenerative Medicine in Oral and Maxillofacial Surgery: The Most Important Innovations in the Clinical Application of Mesenchymal Stem Cells
}

\author{
Marco Tatullo ${ }^{1,2^{*} \bowtie}$, Massimo Marrelli1 ${ }^{12^{*}}$, Francesco Paduano ${ }^{1^{*}}$ \\ 1. Tecnologica Research Institute, Biomedical Section, Crotone, Italy \\ 2. Calabrodental clinic, Biomaterials test unit, Crotone, Italy \\ * All the Authors have equally contributed to this paper \\ $\square$ Corresponding author: Dr. Marco Tatullo, PhD, Scientific Director, Tecnologica Research Institute, Biomedical Section, Str. E. Fermi, \\ Crotone, Italy, Email: marco.tatullo@tecnologicasrl.com \\ (C) Ivyspring International Publisher. This is an open-access article distributed under the terms of the Creative Commons License (http://creativecommons.org/ \\ licenses/by-nc-nd/3.0/). Reproduction is permitted for personal, noncommercial use, provided that the article is in whole, unmodified, and properly cited.
}

Received: 2014.10.02; Accepted: 2014.10.31; Published: 2015.01.01

\begin{abstract}
Regenerative medicine is an emerging field of biotechnology that combines various aspects of medicine, cell and molecular biology, materials science and bioengineering in order to regenerate, repair or replace tissues.

The oral surgery and maxillofacial surgery have a role in the treatment of traumatic or degenerative diseases that lead to a tissue loss: frequently, to rehabilitate these minuses, you should use techniques that have been improved over time. Since 1990, we started with the use of growth factors and platelet concentrates in oral and maxillofacial surgery; in the following period we start to use biomaterials, as well as several type of scaffolds and autologous tissues. The frontier of regenerative medicine nowadays is represented by the mesenchymal stem cells (MSCs): overcoming the ethical problems thanks to the use of mesenchymal stem cells from adult patient, and with the increasingly sophisticated technology to support their manipulation, MSCs are undoubtedly the future of medicine regenerative and they are showing perspectives unimaginable just a few years ago. Most recent studies are aimed to tissues regeneration using MSCs taken from sites that are even more accessible and rich in stem cells: the oral cavity turned out to be an important source of MSCs with the advantage to be easily accessible to the surgeon, thus avoiding to increase the morbidity of the patient.

The future is the regeneration of whole organs or biological systems consisting of many different tissues, starting from an initial stem cell line, perhaps using innovative scaffolds together with the nano-engineering of biological tissues.
\end{abstract}

Key words: Regenerative medicine; Mesenchymal Stem Cells; Bone regeneration; Dental Pulp Stem Cells; human Periapical Cysts Mesenchymal Stem Cells; hPCy-MSCs.

\section{Introduction}

Regenerative medicine is an emerging field of biotechnology that combines various aspects of medicine, cell and molecular biology, materials science and bioengineering in order to regenerate, repair or replace tissues.

The oral surgery and maxillofacial surgery have a role in the treatment of traumatic or degenerative diseases that lead to a tissue loss: frequently, to rehabilitate these minuses, you should use techniques that have been improved over time. Since 1990, tissue engineering has developed protocols in which it has been proposed the use of platelet concentrates, which showed enormous benefits for the patient: they favored and accelerated the post-surgical and provided 
a support for tissue regeneration due to growth factors contained in them. Several authors ${ }^{1-4}$ have described the importance of growth factors in tissue repair processes, in fact, they are important elements for new tissue production, moreover, they perform feedback controls on inflammatory processes within the tissue graft, in cases of regenerative surgery.

Whitman ${ }^{5}$ and Marx ${ }^{6}$ published the first studies on the use of growth factors contained in platelet gel, called Platelet-Rich Plasma (PRP).

Thanks to Marx's studies, it was possible to verify that the platelet concentrate is a very effective tool for the modulation of wound healing and tissue regeneration. However, the PRP showed a number of disadvantages, such as the need of having to run a complex and expensive protocol for its production. To overcome some of these problems, the PRGF (Plasma Rich in Growth Factors) was introduced in the list of platelet concentrates. The PRGF is considered an evolution of the PRP 7,8 and it allows a higher concentration of growth factors in platelet preparation. Among the advantages of the PRGF, we can cite the lesser amount of blood taken for the preparation and a procedure relatively faster, while, among the disadvantages we can mention the rapid clot formation, which require speed in its surgical use.

In 2001, Choukroun et coll. have instead proposed an alternative technique: the PRF (Platelet Rich Fibrin). PRF is derived from a simple preparation protocol that does not require alteration of the blood; it is a platelet concentrate rich in GFs that contains a three-dimensional matrix of autologous, elastic and flexible fibrin.

Dohan et al. have shown that platelet cytokines (PDGF, TGFbeta1 and IGF-1) are present in three-dimensional fibrin matrix derived from these platelet concentrates; moreover, PRF matrix traps glycosaminoglycans such as heparin and hyaluronic acid, which have considerable affinity with some peptides present in the bloodstream and therefore show strong ability of chemotaxis and diapedesis, useful for the healing of tissue damaged, for example, by trauma ${ }^{9}$. Moreover, it was shown that this matrix can be a valuable support for the transplantation of bone morphogenetic proteins (BMP) issued in a progressive manner to induce osteogenic differentiation, as demonstrated by recent studies on muscle preparations ${ }^{10,11}$; about this, the results of Wiltfang et al. are encouraging, in fact, they show an improvement of osteoblast proliferation in cases in which it was used the PRF compared to PRP 12.

Marrelli et al. described a case in which is documented the filling with PRF of a large osteolytic cavity and complete bone reformation ${ }^{13}$. Tatullo et al. have suggested that the osteoinductive potential of
PRF is related to its neoangiogenic ability and concentration of GFs, in relation to the fibrin content and platelet cytokines present, all suitable for the totipotent cell migration and activation of pre-osteoblastic cells present in the surgical site, fundamental aspects for bone regeneration ${ }^{14}$.

Platelets concentrates are, thus, versatile products in surgery, with regard to their biological properties and their easy manipulation in the form of gel or membranes; these features allow the use of PRF as well as other platelet concentrates in cases, for example, of maxillary surgical sites or in the surgery of maxillary sinus ${ }^{15}$.

The frontier of regenerative medicine nowadays is represented by the mesenchymal stem cells (MSCs): overcoming the ethical problems thanks to the use of mesenchymal stem cells from adult patient, and with the increasingly sophisticated technology to support their manipulation, MSCs are undoubtedly the future of medicine regenerative and they are showing perspectives unimaginable just a few years ago. Most recent studies are aimed to tissues regeneration using MSCs taken from sites that are even more accessible and rich in stem cells: the oral cavity turned out to be an important source of MSCs with the advantage to be easily accessible to the surgeon, thus avoiding to increase the morbidity of the patient.

\section{Mesenchymal stem cells of oral origin}

The aim of the regenerative medicine and tissue engineering is to regenerate and repair the damaged cells and tissues in order to establish the normal functions ${ }^{16}$. The regenerative medicine involves the use of biomaterials, growth factors and stem cells ${ }^{17}$. Regeneration of the tissues exists naturally due to the presence of stem cells with the potential to self-regenerate and differentiate into one of more specialized cell types. However, this regenerative potential decreases with age and regeneration is not sufficient to repair the damages produced by degenerative, inflammatory or tumor based diseases ${ }^{18}$. Stem cells are immature and unspecialized cells with the ability to renew and divide themselves indefinitely through "self-renewal" and able to differentiate into multiple cell lineages ${ }^{19}$. The stem cells use for regenerative medicine should fit the following criteria: they can be: a) found in abundant numbers and can be differentiated in multiple cell lineages in a reproducible and controllable manner; $b$ ) isolated by minimally invasive procedure with minimal morbidity for patients, c) produced in accordance with GMP (Good manufacture Practice) and d) transplanted safely ${ }^{20,21}$. In the last decade, several improvements have been produced in the comprehension of stem cells properties in view of the fact that these cells have an important role in the repair of 
every organ and tissue.

In general, the stem cells are divided into three main types that can be utilized for tissue repair and regeneration: $i)$ the embryonic stem cells derived from embryos (ES) 22,23; ii) the adult stem cells that are derived from adult tissue ${ }^{24}$; and iii) the induced pluripotent stem (iPS) cells that have been produced artificially via genetic manipulation of the somatic cells 25. ES and iPS cells are considered pluripotent stem cells because they can develop into all types of cells from all three germinal layers. Both stem cells have technical and moral obstacles, in addition these cells are not easy to control and they can form tumors after injection $^{22}$. On the contrary, adult stem cells are multipotent because they can only differentiate into a restricted number of cell types. Adult stem cells, also termed postnatal stem cells or somatic stem cells, are discovered in a particular area of each tissue named "stem cell niche."

Different type of postnatal stem cells resides in numerous mesenchymal tissues and these cells are at the same time referred to as mesenchymal stem cells (MSCs) ${ }^{24,26}$. MSCs were first isolated and characterized from bone marrow (BMSCs) by Friedenstein et al. in 1974 27. Subsequently, different studies have showed that MSCs can be isolated from other tissues, such as peripheral blood, umbilical cord blood, amniotic membrane, adult connective, adipose and dental tissues ${ }^{28-32}$.

Recently, orofacial and dental tissues have acquired interest as a further accessible source of mesenchymal stem cells ${ }^{33}$ due to the fact that the oral area is rich in MSCs (Table 1). Today, every cell population which has the following characteristics independently of its tissue source, is usually referred as MSCs: $i$ ) they adhere to plastic and have a fibroblast-like morphology; ii) they have the capacity of self-renewal and could differentiate into cells of the mesenchymal lineage such as osteocytes, chondrocytes and adipocytes. In addition, MSCs also can also differentiate, under appropriate conditions, into cells of the endoderm and ectoderm lineages such as hepatocytes and neurons, respectively ${ }^{34,35}$. Phenotypically, MSCs express the CD13, CD29, CD44, CD59, CD73, CD90, CD105, CD146 and STRO-1 surface antigens, and they do not express CD45 (leukocyte marker), CD34 (the primitive hematopoietic progenitor and endothelial cell marker), CD14 and CD11 (the monocyte and macrophage markers), CD79 and CD19 (the B cell markers), or HLA class II ${ }^{36}$. Research related to MSC from oral origin began in $2000{ }^{37}$ and every year numerous investigations have demonstrated that oral tissues, which are simply available for dentists, are a rich source for mesenchymal stem cells ${ }^{33,38}$.

Today numerous types of MSCs have been isolated from teeth: in 2000 MSCs were first isolated by Gronthos et al. from dental pulp (DPSCs) ${ }^{37,38}$. These cells possess phenotypic characteristics similar to those of BMSCs ${ }^{39}$, and they have definitive stem cell properties such as self-renewal and multi- differentiation capacity, and can form the dentin-pulp structure when transplanted into immunocompromised mice ${ }^{40}$. Moreover, DPSCs participate in the regeneration of non-orofacial tissues, in fact, these cells have been differentiated into hair follicle-, hepatocyte-, neuron-, islet-, myocyte- and cardiomyocyte-like cells 41-46. Subsequently, MSCs have been also isolated from dental pulp of human exfoliated deciduous teeth (SHEDs). These cells, like DPSCs, have the ability to differentiate in vitro in odontoblasts, osteoblasts, adipocytes and neuron-like cells. Also SHEDs were able to form dentin and bone when transplanted with HA/TCP in vivo ${ }^{47}$.

Table 1: Mesenchymal Stem Cells from dental tissues

\begin{tabular}{|c|c|c|c|c|c|}
\hline Name & Site & $\begin{array}{l}\text { Date of } \\
\text { discover }\end{array}$ & Authors & Country & Institution \\
\hline DPSCs & Dental Pulp & 2000 & $\begin{array}{l}\text { S. Gronthos, M. Mankani, J. Brahim, P.G. } \\
\text { Robey, S. Shi }\end{array}$ & $\begin{array}{l}\text { USA. } \\
\text { Bethesda, Maryland }\end{array}$ & $\begin{array}{l}\text { National Institute on Dental Research, } \\
\text { National Institutes of Health }\end{array}$ \\
\hline SHED & $\begin{array}{l}\text { human Exfoliated } \\
\text { Deciduous Teeth }\end{array}$ & 2003 & $\begin{array}{l}\text { M. Miura, S. Gronthos, M. Zhao, B. Lu, } \\
\text { L.W. Fisher, P. G. Robey, S. Shi }\end{array}$ & $\begin{array}{l}\text { USA. } \\
\text { Bethesda, Maryland }\end{array}$ & $\begin{array}{l}\text { National Institute on Dental Research, } \\
\text { National Institutes of Health }\end{array}$ \\
\hline PDLSCs & $\begin{array}{l}\text { Periodontal Liga- } \\
\text { ment }\end{array}$ & 2004 & $\begin{array}{l}\text { B. M. Seo, M. Miura, S. Gronthos, P.M. } \\
\text { Bartold, S. Batouli, J. Brahim, M. Young, } \\
\text { P.G. Robey, C.Y. Wang, S. Shi }\end{array}$ & $\begin{array}{l}\text { USA. } \\
\text { Bethesda, Maryland }\end{array}$ & $\begin{array}{l}\text { National Institute on Dental Research, } \\
\text { National Institutes of Health }\end{array}$ \\
\hline SCAP & Apical Papilla & 2006 & $\begin{array}{l}\text { W. Sonoyama, Y. Liu, D. Fang, T. Yamaza, } \\
\text { B.M. Seo, C. Zhang, H. Liu, S. Gronthos, } \\
\text { C.Y. Wang, S. Wang, S. Shi }\end{array}$ & $\begin{array}{l}\text { USA. } \\
\text { Los Angeles, California } \\
\text { JAPAN. } \\
\text { Okayama }\end{array}$ & $\begin{array}{l}\text { University of Southern California School of } \\
\text { Dentistry; } \\
\text { Okayama University Graduate School of } \\
\text { Medicine, Dentistry and Pharmaceutical } \\
\text { Sciences }\end{array}$ \\
\hline DFSCs & Dental Follicle & 2005 & $\begin{array}{l}\text { C. Morsczeck, W. Götz, J. Schierholz, F. } \\
\text { Zeilhofer, U. Kühn, C. Möhl, C. Sippel, } \\
\text { K.H. Hoffmann }\end{array}$ & $\begin{array}{l}\text { GERMANY. } \\
\text { Bonn }\end{array}$ & $\begin{array}{l}\text { Stiftung Caesar, Center of Advanced Eu- } \\
\text { ropean Studies and Research }\end{array}$ \\
\hline hPCy-MSCs & $\begin{array}{l}\text { human Periapical } \\
\text { Cyst }\end{array}$ & 2013 & $\begin{array}{l}\text { M. Marrelli, } \\
\text { F. Paduano, } \\
\text { M. Tatullo }\end{array}$ & $\begin{array}{l}\text { ITALY. } \\
\text { Crotone }\end{array}$ & $\begin{array}{l}\text { Calabrodental, Unit of Maxillofacial Sur- } \\
\text { gery; } \\
\text { Tecnologica Research Institute, Biomedical } \\
\text { Section }\end{array}$ \\
\hline
\end{tabular}


The periodontal ligament is another adult MSCs source in dental tissue, and periodontal ligament stem cells (PDLSCs) were isolated from extracted teeth ${ }^{48}$. PDLSCs have the ability to regenerate periodontal tissues such as the cementum, periodontal ligament and alveolar bone ${ }^{49}$. Moreover, MSCs have been also isolated from developing dental tissues such as the dental follicle (DFPCs) ${ }^{50}$ and apical papilla (SCAPs) ${ }^{51}$. DFPCs have the ability to regenerate periodontal tissues whereas SCAPs demonstrate better proliferation and better regeneration of the dentin matrix when transplanted in immunocompromised mice with compared to DPSCs 50,52,53. Zhang et al. have isolated mesenchymal stem cells from the gingiva, these MSCs exhibited higher clonogenicity, self-renewal and multipotent differentiation capacity similar to that of BMSCs ${ }^{54}$. Moreover, the salivary glands derived MSCs could differentiate into the salivary gland duct cells as well as mucin and amylase producing acinar cells in vitro ${ }^{55}$. In addition, De Bari et al. demonstrated that single-cell-derived clonal populations of adult human periosteal cells possess mesenchymal multipotency, as they differentiate to osteoblast, chondrocyte, adipocyte and skeletal myocyte lineages in vitro and in vivo. Therefore, expanded MSCs isolated from periosteum could be useful for functional tissue engineering, especially for bone regeneration ${ }^{56}$.

The MSCs contained within the bone marrow aspiration from the iliac crest, and liposuction from extra-oral tissue are not easily-accessible stem cells. On the contrary, the orofacial bone marrow, periosteum, salivary glands and dental tissues are the most accessible stem cell sources. Moreover, the isolation of MSCs from these sources may still not be convenient because it requires surgical methods or tooth or pulp extraction. In addition, even if impacted wisdom teeth could be a mesenchymal stem cell source, these MSCs are present in a low percentage and can, therefore, be difficult to isolate, purify and expand. Furthermore, not all adults need the extraction of the wisdom teeth. To overcome these limitations, recently, Marrelli et al. demonstrated that MSCs derived from periapical cysts (hPCy-MSCs) have a mesenchymal stem cell immunophenotype and the ability to differentiate into osteogenic and adipogenic lineages ${ }^{57}$. The periapical cyst, which is a tissue that is easily obtainable and whose cells can be simply expanded from patients with minimal discomfort, seems to be a promising source of adult stem cells in dentistry for regenerative medicine. In fact, a recent study of Marrelli et al. showed that hPCy-MSCs similarly to DPSCs have neural progenitor-like properties by expressing spontaneously neuron and astrocyte specific proteins and neural related genes before any differentiation. Furthermore, hPCy-MSCs, under appropriate neural stimulation, acquire neural morphology and significantly over-express several neural markers at both protein and transcriptional level (in press, not yet published research by Marrelli et al.).

\section{Mesenchymal stem cells in regenerative medicine}

It was reported that MSCs isolated from whole bone marrow aspirates in combination with scaffolds and growth factors are able to repair cranial defects in several animal models 58-60. These studies demonstrated that MSCs can alleviate the complications of craniofacial surgical procedures that required allogenic tissue grafts or extraction of autologous bone from secondary sites. This approach may alleviate donor site morbidity and allow a virtual unlimited source of cellular material derived from allogenic MSCs ${ }^{61}$.

The identification of MSC residing in the oral cavity tissues increases clinical interest in MSCs as a cell source for regeneration of other connective tissues such as cementum, dentin and periodontal ligament (PDL). Many research studies research have been performed to assess the capacity of dental derived MSCs to enhance periodontal regeneration. Seo et al. have demonstrated that human PDLSCs were able to generate a cementum/PDL-like structures when transplanted into immunocompromised mice, and consequently transplantation of PDLSCs could be considered as a therapeutic approach for regeneration of tissues damaged by periodontal diseases ${ }^{48}$. Moreover, Kim et al. compared the alveolar bone regeneration achieved from implantation of PDLSCs and BMSCs and identified no significant difference in regenerative potential in vivo between these MSCs ${ }^{62}$.

The three key elements in the field of tissue engineering are stem cells, scaffolds and growth factors 63. Recently, researchers are trying to identify the ideal scaffold that facilitate growth, cell spreading, adhesion, integration and differentiation of MSCs. This scaffold should be biocompatible and biodegradable, should have optimal physical features and mechanical properties ${ }^{64}$. Different material have been designed and constructed for tissue engineering approaches, using natural or synthetic polymers or inorganic materials, which have been fabricated into porous scaffolds, nanofibrous material, hydrogels and microparticles. Natural materials include collagen, elastin, fibrin, silk, chitosan and glycosaminoglycans ${ }^{65}$. Recently, hydrogels have been investigated for tissue engineering applications because they offer numerous properties including biocompatibility and mechanical characteristics similar to those of native tissue 66,67 . Synthetic poly lactic-co-glycolic acid (PLGA) and titanium provide excellent chemical and mechanical 
properties for bone tissue regeneration in vivo using DPSCs ${ }^{68}$. Furthermore, recent studies demonstrated that DPSCs loaded onto scaffolds of chitosan formed a dentine-pulp complex in vivo ${ }^{69}$ whereas DPSCs cultured on hydroxyapatite (HA) and placed subcutaneously in nude mice formed bone ${ }^{70}$. A great number of investigations for evaluating the in vivo application of MSCs isolated from the oral cavity were carried out on animal models. A clinical study conducted by Papaccio's group gave evidence of the possibility to utilise DPSCs to repair bone defect in humans. In fact, they showed that DPSCs/collagen biocomplex completely restored human mandible bone defects subsequent to DPSCs transplantation ${ }^{71}$.

\section{Conclusions}

The future is the regeneration of whole organs and complex biological systems consisting of many different tissues, starting from an initial stem cell line, probably using innovative scaffolds together with the nano-engineering of biological tissues: this approach is already a research topic in several international research institutes, and the best way to merge the numerous skills needed to get a so ambitious result is the multicenter collaboration. The authors are closely collaborating together with high-level international Universities, to develop protocols aimed to control and lead the tissues regeneration. This goal could make born a new generation of stem-cells based therapies, so to open the door to a new highly-performing regenerative medicine.

Starting from 2000, in only fifteen years, researchers have changed the face of the tissues engineering and the expectation of quality of life in more than 2 billions of patients undergone to a regenerative surgery: the challenge is to continue to make the patient's life better, to make the surgery more predictable and to simply replace damaged or degenerated tissues with MSCs from dental and oral sources.

\section{Acknowledgements}

The present study was supported by "PROMETEO Project - Progettazione e Sviluppo di piattaforme tecnologiche innovative ed ottimizzazione di PROcessi per applicazioni in MEdicina rigenerativa in ambito oromaxillofaciale, emaTologico, nEurologico e cardiOlogico". PON01_02834.

\section{Competing Interests}

The authors have declared that no competing interest exists.

\section{References}

1. Gibble JW, Ness PM. Fibrin glue: the perfect operative sealant? Transfusion. 1990;30:741-7

2. Saltz R, Sierra D, Feldman D, Saltz MB, Dimick A, Vasconez LO. Experimental and clinical applications of fi brin glue. Plast Reconstr Surg. 1991;88:1005-15, discussion 1016-7.

3. Hotz G. Alveolar ridge augmentation with hydroxylapatite using fibrin sealant for fixation. Part I: An experimental study. Int J Oral Maxillofac Surg. 1991; 20:204-7.

4. Hotz G. Alveolar ridge augmentation with hydroxylapatite using fi brin sealant for fi xation. Part II: Clinical application. Int J Oral Maxillofac Surg. 1991; 20:208-13.

5. Whitman DH, Berry R, Green D. Platelet gel: an autologous alternative to fibrine glue with applications in oral and maxillofacial surgery. J Oral Maxillofac Surg. 1997; 55: 1294-9.

6. Marx RE, Carlson ER, Eichstaedt RM, et al. Platelet-rich plasma: growth factor enhancement for bone grafts. Oral Surg Oral Med Oral Pathol Oral Radiol Endod. $1998 ; 85: 638-46$

7. Weibrich G, Kleis WKG, Hitzler WE, Hafner G. Comparison of the Platelet Concentrate Collection System with the Plasma-Rich-in-Growth-Factors Kit to Produce Platelet-Rich Plasma: A Technical Report. Int J Oral Maxillofac Implants. 2005;20:118-123.

8. Weibrich G, Kleis WKG, Hafner G, Hitzler WE, Wagner W. Comparison of platelet, leukocyte and growth factor levels in point of care platelet-enriched plasma, prepared using a modified Curasan kit, with preparations received from a local blood bank. Clin Oral Implant Res. 2005; 14: 357-362.

9. Gibble JW, Ness PM. Fibrin glue: the perfect operative sealant? Transfusion 1990;30:741-7.

10. Mosesson MW, Siebenlist KR, Meh DA. The structure and biological features of fibrinogen and fibrin. Ann N YAcad Sci. 2001;936:11-30.

11. Kawamura M, Urist MR. Human fibrin is a physiologic delivery system for bone morphogenic protein. Clin Orthop. 1988; 235: 302-10.

12. Wiltfang J, Kloss FR, Kessler P, Nkenke E, Zimmerman R, Schlegel KA. Effect of prp on bone healing in combination whit autogenous bone end bone substitutes incritical-size defects. An animal experiment. Clin Oral Implants Res. 2004; 15: 187-93

13. Marrelli M, Pacifici A, Di Giorgio G, Cassetta M, Stefanelli LV, Gargari M, Promenzio L, Annibali S, Cristalli MP, Chiaravalloti E, Pacifici L, Tatullo M. Diagnosis and treatment of a rare case of adenomatoid odontogenic tumor in a young patient affected by attenuated familial adenomatosis polyposis (aFAP): case report and 5 year follow-up. Eur Rev Med Pharmacol Sci. 2014;18(2):265-9.

14. Tatullo M, Marrelli M, Cassetta M, Pacifici A, Stefanelli LV, Scacco S, Dipalma G, Pacifici L, Inchingolo F. Platelet Rich Fibrin (P.R.F.) in reconstructive surgery of atrophied maxillary bones: clinical and histological evaluations. Int $J$ Med Sci. 2012;9(10):872-80. doi: 10.7150/ijms.5119. Epub 2012 Nov 7.

15. Marrelli M, Tatullo M. Influence of PRF in the healing of bone and gingival tissues. Clinical and histological evaluations. Eur Rev Med Pharmacol Sci. 2013 Jul;17(14):1958-62.

16. Mason C, Dunnill P. A brief definition of regenerative medicine. Regenerative medicine 2008; 3: 1-5

17. Sundelacruz S, Kaplan DL. Stem cell- and scaffold-based tissue engineering approaches to osteochondral regenerative medicine. Seminars in cell $\mathcal{E}$ developmental biology 2009; 20: 646-655

18. Rodriguez-Lozano FJ, Bueno C, Insausti CL, Meseguer L, Ramirez MC, Blanquer M, Marin N, Martinez S, Moraleda JM. Mesenchymal stem cells derived from dental tissues. International endodontic journal 2011; 44: 800-806

19. Weissman IL. Stem cells: Units of development, units of regeneration, and units in evolution. Cell 2000; 100: 157-168.

20. Gimble JM, Katz AJ, Bunnell BA. Adipose-derived stem cells for regenerative medicine. Circulation research 2007; 100: 1249-1260

21. Gimble JM. Adipose tissue-derived therapeutics. Expert opinion on biological therapy 2003; 3: 705-713

22. Evans MJ, Kaufman MH. Establishment in culture of pluripotential cells from mouse embryos. Nature 1981; 292: 154-156

23. Martin GR. Isolation of a pluripotent cell line from early mouse embryos cultured in medium conditioned by teratocarcinoma stem cells. Proceedings of the National Academy of Sciences of the United States of America 1981; 78: 7634-7638

24. Korbling M, Estrov Z. Adult stem cells for tissue repair - a new therapeutic concept? The New England journal of medicine 2003; 349: 570-582

25. Yu J, Vodyanik MA, Smuga-Otto K, Antosiewicz-Bourget J, Frane JL, Tian S, Nie J, Jonsdottir GA, Ruotti V, Stewart R, Slukvin II, Thomson JA. Induced pluripotent stem cell lines derived from human somatic cells. Science 2007; 318: 1917-1920

26. Keating A. Mesenchymal stromal cells: New directions. Cell stem cell 2012; 10: 709-716

27. Friedenstein AJ, Chailakhyan RK, Latsinik NV, Panasyuk AF, Keiliss-Borok IV. Stromal cells responsible for transferring the microenvironment of the hemopoietic tissues. Cloning in vitro and retransplantation in vivo. Transplantation $1974 ; 17: 331-340$

28. Zhang Y, Huang B. Peripheral blood stem cells: Phenotypic diversity and potential clinical applications. Stem cell reviews 2012; 8: 917-925

29. Zarrabi M, Mousavi SH, Abroun S, Sadeghi B. Potential uses for cord blood mesenchymal stem cells. Cell journal 2014; 15: 274-281 
30. Bongso A, Fong CY. The therapeutic potential, challenges and future clinical directions of stem cells from the wharton's jelly of the human umbilical cord. Stem cell reviews 2013; 9: 226-240

31. Romagnoli C, Brandi ML. Adipose mesenchymal stem cells in the field of bone tissue engineering. World journal of stem cells 2014; 6: 144-152

32. Egusa H, Sonoyama W, Nishimura M, Atsuta I, Akiyama K. Stem cells in dentistry--part i: Stem cell sources. Journal of prosthodontic research 2012; 56: 151-165

33. Mao JJ, Prockop DJ. Stem cells in the face: Tooth regeneration and beyond. Cell stem cell 2012; 11: 291-301

34. Wu XB, Tao R. Hepatocyte differentiation of mesenchymal stem cells. Hepatobiliary \& pancreatic diseases international: HBPD INT 2012; 11: 360-371

35. Ferroni L, Gardin C, Tocco I, Epis R, Casadei A, Vindigni V, Mucci G, Zavan B. Potential for neural differentiation of mesenchymal stem cells. Advances in biochemical engineering/biotechnology 2013; 129: 89-115

36. Dominici M, Le Blanc K, Mueller I, Slaper-Cortenbach I, Marini F, Krause D, Deans R, Keating A, Prockop D, Horwitz E. Minimal criteria for defining multipotent mesenchymal stromal cells. The international society for cellular therapy position statement. Cytotherapy 2006; 8: 315-317

37. Gronthos S, Mankani M, Brahim J, Robey PG, Shi S. Postnatal human dental pulp stem cells (dpscs) in vitro and in vivo. Proceedings of the National Academy of Sciences of the United States of America 2000; 97: 13625-13630

38. Tatullo M, Marrelli M, Shakesheff KM, White LJ. Dental pulp stem cells: function, isolation and applications in regenerative medicine. J Tissue Eng Regen Med. 2014; doi: 10.1002/term.1899

39. Shi S, Robey PG, Gronthos S. Comparison of human dental pulp and bone marrow stromal stem cells by cdna microarray analysis. Bone 2001; 29: 532-539

40. Gronthos S, Brahim J, Li W, Fisher LW, Cherman N, Boyde A, DenBesten P, Robey PG, Shi S. Stem cell properties of human dental pulp stem cells. Journal of dental research 2002; 81: 531-535

41. Reynolds AJ, Jahoda CA. Cultured human and rat tooth papilla cells induce hair follicle regeneration and fiber growth. Differentiation; research in biological diversity 2004; 72: 566-575

42. Iohara K, Zheng L, Ito M, Tomokiyo A, Matsushita K, Nakashima M. Side population cells isolated from porcine dental pulp tissue with self-renewal and multipotency for dentinogenesis, chondrogenesis, adipogenesis, and neurogenesis. Stem cells (Dayton, Ohio) 2006; 24: 2493-2503

43. Ishkitiev $\mathrm{N}$, Yaegaki $\mathrm{K}$, Calenic $\mathrm{B}$, Nakahara $\mathrm{T}$, Ishikawa $\mathrm{H}$, Mitiev $\mathrm{V}$, Haapasalo M. Deciduous and permanent dental pulp mesenchymal cells acquire hepatic morphologic and functional features in vitro. Journal of endodontics 2010; 36: 469-474

44. Yang R, Chen M, Lee CH, Yoon R, Lal S, Mao JJ. Clones of ectopic stem cells in the regeneration of muscle defects in vivo. PloS one 2010; 5: e13547

45. Sugiyama M, Iohara K, Wakita $H$, Hattori $H$, Ueda M, Matsushita K, Nakashima M. Dental pulp-derived cd31(-)/cd146(-) side population stem/progenitor cells enhance recovery of focal cerebral ischemia in rats. Tissue engineering Part A 2011; 17: 1303-1311

46. Govindasamy V, Ronald VS, Abdullah AN, Ganesan Nathan KR, Aziz ZA, Abdullah M, Zain RB, Kasim NH, Musa S, Bhonde RR. Human platelet lysate permits scale-up of dental pulp stromal cells for clinical applications. Cytotherapy 2011; 13: 1221-1233

47. Miura M, Gronthos S, Zhao M, Lu B, Fisher LW, Robey PG, Shi S. Shed: Stem cells from human exfoliated deciduous teeth. Proceedings of the National Academy of Sciences of the United States of America 2003; 100: 5807-5812

48. Seo BM, Miura M, Gronthos S, Bartold PM, Batouli S, Brahim J, Young M, Robey PG, Wang CY, Shi S. Investigation of multipotent postnatal stem cells from human periodontal ligament. Lancet 2004; 364: 149-155

49. Seo BM, Miura M, Sonoyama W, Coppe C, Stanyon R, Shi S. Recovery of stem cells from cryopreserved periodontal ligament. Journal of dental research 2005; 84: 907-912

50. Morsczeck C, Gotz W, Schierholz J, Zeilhofer F, Kuhn U, Mohl C, Sippel C, Hoffmann KH. Isolation of precursor cells (pcs) from human dental follicle of wisdom teeth. Matrix biology :journal of the International Society for Matrix Biology 2005; 24: 155-165

51. Sonoyama W, Liu Y, Yamaza T, Tuan RS, Wang S, Shi S, Huang GT. Characterization of the apical papilla and its residing stem cells from human immature permanent teeth: A pilot study. Journal of endodontics 2008; 34: 166-171

52. Yao S, Pan F, Prpic V, Wise GE. Differentiation of stem cells in the dental follicle. Journal of dental research 2008; 87: 767-771

53. Huang GT, Sonoyama W, Liu Y, Liu H, Wang S, Shi S. The hidden treasure in apical papilla: The potential role in pulp/dentin regeneration and bioroot engineering. Journal of endodontics 2008; 34: 645-651

54. Zhang Q, Shi S, Liu Y, Uyanne J, Shi Y, Shi S, Le AD. Mesenchymal stem cells derived from human gingiva are capable of immunomodulatory functions and ameliorate inflammation-related tissue destruction in experimental colitis. Journal of immunology (Baltimore, Md : 1950) 2009; 183: 7787-7798

55. Kishi T, Takao T, Fujita K, Taniguchi H. Clonal proliferation of multipotent stem/progenitor cells in the neonatal and adult salivary glands. Biochemical and biophysical research communications 2006; 340: 544-552

56. De Bari C, Dell'Accio F, Vanlauwe J, Eyckmans J, Khan IM, Archer CW, Jones EA, McGonagle D, Mitsiadis TA, Pitzalis C, Luyten FP. Mesenchymal multipotency of adult human periosteal cells demonstrated by single-cell lineage analysis. Arthritis and rheumatism 2006; 54: 1209-1221
57. Marrelli M, Paduano F, Tatullo M. Cells isolated from human periapical cysts express mesenchymal stem cell-like properties. International journal of biological sciences 2013; 9: 1070-1078

58. van den Dolder J, Farber E, Spauwen PH, Jansen JA. Bone tissue reconstruction using titanium fiber mesh combined with rat bone marrow stromal cells. Biomaterials 2003; 24: 1745-1750

59. Krebsbach PH, Mankani MH, Satomura K, Kuznetsov SA, Robey PG. Repair of craniotomy defects using bone marrow stromal cells. Transplantation 1998; 66: $1272-1278$

60. Schantz JT, Hutmacher DW, Lam CX, Brinkmann M, Wong KM, Lim TC, Chou N, Guldberg RE, Teoh SH. Repair of calvarial defects with customised tissue-engineered bone grafts ii. Evaluation of cellular efficiency and efficacy in vivo. Tissue engineering 2003; 9 Suppl 1: S127-139

61. Shi S, Bartold PM, Miura M, Seo BM, Robey PG, Gronthos S. The efficacy of mesenchymal stem cells to regenerate and repair dental structures. Orthodontics \& craniofacial research 2005; 8: 191-199

62. Kim SH, Kim KH, Seo BM, Koo KT, Kim TI, Seol YJ, Ku Y, Rhyu IC, Chung CP, Lee YM. Alveolar bone regeneration by transplantation of periodontal ligament stem cells and bone marrow stem cells in a canine peri-implant defect model: A pilot study. Journal of periodontology 2009; 80: 1815-1823

63. Rodriguez-Lozano FJ, Insausti CL, Iniesta F, Blanquer M, Ramirez MD, Meseguer L, Meseguer-Henarejos AB, Marin N, Martinez S, Moraleda JM. Mesenchymal dental stem cells in regenerative dentistry. Medicina oral, patologia oral y cirugia bucal 2012; 17: e1062-1067

64. La Noce M, Paino F, Spina A, Naddeo P, Montella R, Desiderio V, De Rosa A, Papaccio G, Tirino V, Laino L. Dental pulp stem cells: State of the art and suggestions for a true translation of research into therapy. Journal of dentistry 2014; 42: 761-768

65. Galler KM, D'Souza RN. Tissue engineering approaches for regenerative dentistry. Regenerative medicine 2011; 6: 111-124

66. Smith EL, Kanczler JM, Gothard D, Roberts CA, Wells JA, White LJ, Qutachi O, Sawkins MJ, Peto H, Rashidi H, Rojo L, Stevens MM, El Haj AJ, Rose FR, Shakesheff KM, Oreffo RO. Evaluation of skeletal tissue repair, part 1: Assessment of novel growth-factor-releasing hydrogels in an ex vivo chick femur defect model. Acta biomaterialia 2014; doi: 10.1016/j.actbio.2014.06.011

67. Smith EL, Kanczler JM, Gothard D, Roberts CA, Wells JA, White LJ, Qutachi O, Sawkins MJ, Peto H, Rashidi H, Rojo L, Stevens MM, El Haj AJ, Rose FR, Shakesheff KM, Oreffo RO. Evaluation of skeletal tissue repair, part 2: Enhancement of skeletal tissue repair through dual-growth-factor-releasing hydrogels within an ex vivo chick femur defect model. Acta biomaterialia 2014; doi: 10.1016/j.actbio.2014.05.025

68. Graziano A, d'Aquino R, Cusella-De Angelis MG, De Francesco F, Giordano A, Laino G, Piattelli A, Traini T, De Rosa A, Papaccio G. Scaffold's surface geometry significantly affects human stem cell bone tissue engineering. Journal of cellular physiology 2008; 214: 166-172

69. Yang X, Han G, Pang X, Fan M. Chitosan/collagen scaffold containing bone morphogenetic protein-7 DNA supports dental pulp stem cell differentiation in vitro and in vivo. Journal of biomedical materials research Part A 2012; doi: 10.1002/jbm.a.34064

70. Yang X, van der Kraan PM, Bian Z, Fan M, Walboomers XF, Jansen JA. Mineralized tissue formation by bmp2-transfected pulp stem cells. Journal of dental research 2009; 88: 1020-1025

71. d'Aquino R, De Rosa A, Lanza V, Tirino V, Laino L, Graziano A, Desiderio V, Laino G, Papaccio G. Human mandible bone defect repair by the grafting of dental pulp stem/progenitor cells and collagen sponge biocomplexes. European cells \& materials 2009; 18 : 75-83 